\title{
Monocyte chemoattractant protein-1 in glomerular disease and renal transplantation
}

\author{
Wiguno Prodjosudjadi
}

\begin{abstract}
Abstrak
Infiltrasi makrofag pada glomerulus atau tubulointerstitium_mempunyai peran penting pada patogenesis berbagai penyakit ginjal. Pemahaman mekanisme yang bertanggung jawab atas terjadinya migrasi monosit dari intravaskuler ke tempat kerusakan jaringan sekarang mulai meningkat. Salah satu sitokin kemotaktik yang terlibat pada migrasi monosit adalah MCP-I (monocyte chemoattractant protein-1). Makalah ini merupakan kilas balik (review) penelitian kami dan penelitian lain tentang peran MCP-I pada migrasi monosit ke dalam glomerulus dan tubulointerstitium pada berbagai penyakit glomeruler dan rejeksi akut ginjal cangkok.
\end{abstract}

\begin{abstract}
Infiltration of macrophages in the glomeruli or tubulointerstitium play an important role in the pathogenesis of various types of renal disease. The mechanisms responsible for the migration of monocytes from the intravascular compartment to the place of tissue injury are now increasingly understood. Monocyte chemoattractant protein-1 (MCP-1) is one of chemotactic cytokines involved in the migration of monocytes. This paper reviewed our studies and others on the role of $M C P-1$ in the migration of monocytes into the glomeruli and tubulointerstitium, in glomerular diseases and acute renal allograft rejection.
\end{abstract}

Keywords : Renal allograft rejection, glomeruli, tubulointerstitium

Glomerular diseases are still a major cause of end stage renal disease. Renal damage in glomerulonephritis $(\mathrm{GN})$ is an immune response against intrinsic as well as extrinsic antigens. Immune complex deposition both from the circulation or in situ deposition initiates the inflammatory process of the glomeruli leading to renal injury. This process is characterized by infiltration of mononuclear or polymorphonuclear leukocytes. It has become clear recently that various proinflammatory mediators released by infiltrating cells play an important role in the pathogenesis of glomerular diseases. In various types of glomerular disease, macrophages are found as a predominant phenotype of infiltrating cells in the glomeruli. Recently, evidence showed that tubulointerstitial changes have a significant correlation with the progression of disease manifested by deterioration of renal function.' These changes are characaterized by infiltration of macrophages, tubular atrophy, and eventually, renal fibrosis of the interstitium. The role

Division of Nephrology, Department of Internal Medicine Faculty of Medicine, University of Indonesia/Dr. Cipto Mangunkusumo Hospital, Jakarta, Indonesia of macrophages in the pathogenesis of glomerular diseases has been extensively studied in experimental animals as well as in humans. The mechanisms responsible for the migration of monocytes from intravascular compartment into the site of injury are now increasingly understood. Several factors such as adhesion molecules and chemotactic cytokines are involved in the migration of inflammatory cells. ${ }^{2}$ This paper reviews our studies and others, and focuses on the role of chemotactic factor MCP-1 (monocyte chemoattractant protein-1) in the migration of macrophages into the glomeruli and renal interstitium in glomerular disease and acute renal transplant rejection.

\section{The migration process of monocytes / macrophages}

The cellular directional movement on the basis of a concentration gradient of chemotactic factor -is defined as a chemotaxis. With regard to the monocyte chemotaxis, the presence of a member of the chemotactic cytokines (MCP-1) has been described as an important chemoattractant for monocytes. ${ }^{3}$ MCP-1 is a basic protein, with a molecular weight of $8.7 \mathrm{kDa}$ as assessed by amino acid sequence. This protein 
migrates as 15 and $13 \mathrm{kDa}$ band in SDS-PAGE, namely MCP- $1 \alpha$ and MCP- $1 \beta$, respectively. Since both of MCP-1 can not be distinguished by amino acid sequence and also were precipitated by a rabbit antibody induced by pure MCP-1 $\beta$, it has been assumed that both MCP-1 represent a single gene products. The molecular weight differences are based on the differences of the glycosylation, eventhough, does not affect their capacity as chemotactic factor. ${ }^{4}$ Chemokines, including MCP-1, bind to cell surface G-linked receptors and initiate changes in cell function, shape and expression of molecule involved in adhesion. The expression of $\mathrm{MCP}-1$ receptor (CCR1) was found on the cell surface of monocytes and activated $\mathrm{T}$ lymphocytes but not on the neutrophils. ${ }^{2}$ Therefore, MCP-1 is a specific chemotactic factor for monocytes as well as $\mathrm{T}$ lymphocytes, but not for neutrophils. MCP-1 is produced by several renal cells such as glomerular cells and proximal tubular epithelial cells and various non-renal cells. The production of MCP-1 is increased under the stimulation of IL-1, TNF- $\alpha$, and interferon gamma (INF- $\gamma$ ).,

Adhesion molecules are also involved in the migration of inflammatory cells, including monocytes. The four coordinated steps in the migration process are tethering and rolling, trigerring, strong adhesion, and transendothelial migration. In the early stage, tethering and rolling of the leukocytes on the endothelial cell surface are mediated by adhesion molecule selectins. The interaction between leukocytes and vascular endothelial cells is mediated by carbohydrate-containing counter-receptors through the binding of leukocyte selectin (L selectin) or endothelial selectins ( $\mathrm{E}$ and $\mathrm{P}$ selectins). In renal diseases, glomerular endothelial cells promote leukocyte adhesion through the expression of Lselectin following exposure to proinflammatory cytokines. ${ }^{7}$ In the second step, leukocytes have been trigerred by various chemokines or molecules such as CD31 or platelet-endothelial cell adhesion molecule-1 (PECAM-1) released by activated endothelial cells. This signaling event causes the activation of integrins on leukocytes, arrest the rolling process, subsequently proceeding to a strong adhesion of leukocyte on the endothelial cell surface. The tight adhesion involves the interaction between VLA-4 (very late antigen-4) on leukocytes and VCAM-1 (vascular cell adhesion molecule-1) which is expressed by stimulated endothelial cells. ${ }^{7}$ Lymphocyte function-associated antigen-1 (LFA-1) secures the firm attachment of leukocytes on the endothelial cell surface via its interaction with intercellular adhesion molecule-1 (ICAM-1) present on endothelial cells. The strong adhesion between leukocytes and endothelial cell surface is not permanent. This interaction is loosened sufficiently for leukocytes or monocytes to transmigrate without being swept away by the flowing blood. Infiltrating macrophages are capable of secreting a wide range of inflammatory mediators, which has been associated with, or have been demonstrated to cause glomerular injury.

\section{The role of MCP-1 in the influx of macrophages into the glomeruli}

Infiltration of macrophages into the glomeruli have been reported in various types of proliferative GN, especially crescentic GN. The number of macrophages in the glomeruli correlates with the level of proteinuria, therefore, it has been assumed that macrophages participate in glomerular injury. The role of MCP-1 in the recruitment of macrophages into the glomeruli has been studied both in humans and in experimental animals. ${ }^{8}$ Our study demonstrated that in renal biopsy of patients with extracapillary proliferative GN, membrano-proliferative $\mathrm{GN}$ and lupus nephritis, the numbers of glomerular infiltration of macrophages are increased as compared to normal kidneys. ${ }^{9}$ Based on the result of this study, we expect that the intensity of MCP-1 staining in the glomeruli using IgG anti-MCP-1 polyclonal antibody would be increased in these diseases. However, the intensity of MCP-1 staining was found not to be significantly increased. Surprisingly, in membranous nephropathy the non-inflammatory type of GN, the intensity of MCP-1 staining in the glomeruli was significantly stronger than that in normal kidneys. Rovin et al: reported that glomerular MCP-1 was found in human inflammatory glomerulopathies, but not in glomerular diseases lacking a prominent monocyte infiltrate such as membranous nephropathy. ${ }^{8}$ The increased intensity of MCP-1 staining in the glomeruli of membranous nephropathy, particularly the strong intensity of MCP1 staining by glomerular visceral epithelial cells (GVEC), motivated us to perform an in vitro study to investigate whether human GVEC produce MCP-1. Our study found that IL- $1 \alpha$ and TNF- $\alpha$ stimulate the production of MCP-1 by GVEC. ${ }^{10}$ It was shown that in GVEC culture, the culture medium containing IL$1 \alpha 250 \mathrm{pg} / \mathrm{mL}$ or TNF- $\alpha 250 \mathrm{U} / \mathrm{mL}$, significantly increased the production of MCP-1 by $1.14 \pm 0.26$ 
$\mathrm{ng} / 10^{4}$ cells and $1.15 \pm 0.02 \mathrm{ng} / 10^{4}$ cells, respectively, as compared to $0.59 \pm 0.23 \mathrm{ng} / 10^{4}$ cells cultured in medium alone. Cycloheximide was able to inhibit the production of MCP-1 by $77 \%$ and the inhibitory effect was fully reversible by culturing the cells without cycloheximide. This fact indicates de novo production of MCP-1 by GVEC. Northern blot analysis also demonstrated that the expression of MCP-1 mRNA was clearly up-regulated by $\mathrm{IL}-1 \alpha$ and TNF- $\alpha .^{10}$ These findings suggest that MCP-1 might play a role in the development of glomerular injury in various types of glomerular disease. Furthermore, MCP-1 staining in GVEC was also found to be higher in glomerulosclerosis than in normal kidneys. The primary damage of GVEC and glomerular macrophages has been held responsible for the development of glomerulosclerosis. ${ }^{1,12}$ Probably, MCP-1 produced by GVEC plays an additional role in the influx of monocytes into the glomeruli. Macrophages and GVEC do participate in the formation of crescents which may occur as a complication in many forms of glomerular disease including membranous nephropathy. Glomerular expression of MCP-1 both in the level of mRNA and protein, has been reported to be increased in experimental crescentic GN in rats. ${ }^{1.3}$ Therefore, we speculate that MCP-1 derived from GVEC plays an additional role in the formation of crescents. Further studies are needed to confirm this speculation.

\section{The role of MCP-1 in the migration of macrophages into the interstitium}

Infiltration of macrophages are not only important in the glomeruli but also in the interstitium. In almost all types of glomerular diseases, $\mathrm{T}$ lymphocytes and macrophages are the predominant cell types observed in the tubulointerstitium. The degree of interstitial infiltrate correlates well with the decline of renal function. ${ }^{14}$ Our study demonstrated that the number of infiltrating macrophages in the tubulointerstitium was significantly increased in all types of glomerular disease as compared to normal kidneys. The number of macrophages in the tubulointerstitium correlates inversely with the degree of renal impairment. ${ }^{9}$ This study also showed that the intensity of MCP-1 staining in tubular epithelial cells in renal biopsies of patients with membranous nephropathy, IgA nephropathy, and glomerulosclerosis is stronger than the MCP-1 staining in normal kidneys. The intensity of MCP-1 staining in proximal tubular epithelial cells (PTEC) in these diseases is associated with a significant increase of interstitial macrophages. ${ }^{9}$ This finding was supported by the fact that macrophages can be observed in the vicinity of MCP-1 positive tubular epithelial cells. ${ }^{15}$ Furthermore, our in vitro study showed that human PTEC obtained from kidneys are not suitable for renal transplantation, produce MCP-1 and the production is increased in the presence of inflammatory cytokines $\mathrm{IL}-1 \alpha$ and TNF$\alpha{ }^{15}$ This finding is supported by the data obtained from Northern blot analysis and the fact that IL-1- or TNF- $\alpha$ stimulated PTEC markedly induced the expression of MCP-1 mRNA. These findings indicate that MCP-1 is produced by PTEC in situ. Since MCP-1 isolated from supernatants of PTEC cultures has a chemotactic activity on monocytes as assessed using a 48-well modified Boyden chamber, it is suggested that local production of MCP-1 by PTEC plays a role in the migration of monocytes into the tubulointerstitium. The fact that the intensity of MCP-1 staining in tubular epithelial cells was not significantly increased in membranoproliferative GN, extracapillary proliferative GN and lupus nephritis despite the increased number of macrophages in the tubulointerstitium suggests that there are factors other than MCP-1 that are responsible for the directed migration of monocytes. ${ }^{9}$ Another possible explaination for the discrepancy between the intensity of MCP-1 staining in tubular epithelial cells and the number of macrophages in the tubulointerstitium is the ability of infiltrating macrophages to proliferate locally. This evidence was also observed in the experimental model of anti-GBM nephritis in rats and in the model of acute allograft rejection. ${ }^{16,17}$

In acute renal transplant rejection, macrophages and $\mathrm{T}$ lymphocytes are found in the tubulointerstitium. Using an immunohistochemical analysis we demostrated a significant increase of peritubular macrophages in renal allograft biopsies of patient with acute rejection. ${ }^{9}$ Moreover, the high intensity of MCP-1 staining is also found in tubular epithelial cells of renal biopsies with acute renal transplant rejection. These findings motivated us to evaluate the role of MCP- 1 in renal transplantation. We demonstrated that urinary excretion of MCP-1 is significantly higher in patients with acute rejection as compared to the patients without rejection. ${ }^{18}$ We also found that fractional excretion of MCP-1 was significantly higher in patients with acute rejection than those without rejection. The fractional excretion of MCP-1 was calculated on the basis of MCP-1 and creatinine clearances, therefore, this parameter may give more reliable impression of MCP-1 renal handling. Glomerular filtration rate (GFR) decreases during acute 
rejection and the fractional excretion of MCP-1 is around $100 \%$. In some samples, the fractional excretion can even be more than $100 \%$. This fact indicate that the increase of MCP-1 excretion in the urine during episode of acute rejection is the result of local production by tubular epithelial cells. ${ }^{18}$ However, the possible contribution of macrophage-derived MCP-1 in the urine could not be excluded. MCP-1 locally produced by tubular epithelial cells may induce the influx of macrophages into the intertsitium during the episode of acute rejection. Of course, factors other than MCP-1 should also be considered as mediators responsible for the migration of monocytes into the tubulointerstitial space. Interferon gamma released by activated $T$ lymphocytes which are involved in acute renal allograft rejection, up-regulates the expression of ICAM-1 and VCAM-1 by tubular epithelial cells. ${ }^{19,20}$ Moreover, our in vitro study showed that IFN- $\gamma$ stimulates the production of MCP-1 by PTEC in culture. ${ }^{15}$ These findings suggest that MCP-1, at least in part, is responsible in the migration of monocytes into the interstitium during rejection. Interestingly, in episodes of acute rejection based on clinical grounds and histology of renal biopsy, the increase of urinary MCP-1 excretion preceded the increase of serum creatinine in $64 \%$ of the cases, and was observed the day before renal biopsy in $82 \%$ of the cases. ${ }^{18}$ These findings suggest that increased urinary excretion of MCP-1 can be used as a marker for acute renal allograft rejection. In other study we investigated the role of serum concentration and urinary excretion of $\mathbb{L}-6$ or $\mathbb{L}-8$ as markers for acute renal transplant rejection and compared with urinary excretion of MCP-1 [unpublished data]. We observed that urinary excretion of MCP-1 is a better marker to diagnose the episodes of acute rejection than urinary excretion of IL-6. Serum level of IL-6 or IL-8 and the urinary excretion of IL-8 can not be used as reliable markers for the detection of acute rejection.

\section{Potential role of MCP-1 for future intervention}

The role of MCP-1 in the influx of macrophages into the glomeruli and the tubulointerstitium was investigated in order to obtain the insight into the pathogenesis of various types of glomerular disease and the development of acute renal transplant rejection. ${ }^{21,22}$ The infiltration of macrophages plays an important role in glomerular injury. This finding suggests that the application of anti-MCP-1 antibody may inhibit the inflammatory process. Furthermore, it was observed in nephrotoxic nephritis model that anti-MCP-1 antibodies reduced macrophage infiltration and proteinuria. ${ }^{23}$

\section{CONCLUSIONS}

The studies reported in this paper suggest that MCP-1 plays a role in the infiltration of macrophages into the tubulointertstitial in different types of glomerular disease such as membranous nephropathy, IgA nephropathy, and glomerulosclerosis. The role of GVEC derived MCP-1 on the inlux of macrophages into the glomeruli is not fully clear, however, we speculate that this chemokine plays an additional role in the formation of crescents, especially in membranous nephropathy. Proximal tubular epithelial cells are sources of MCP-1, and locally produced MCP-1 by PTEC plays a role in the influx of macrophages in various type of glomerular diseases and in acute renal transplant rejection. Urinary excretion of MCP-1 can be used as a potential marker for the detection of acute rejection.

\section{REFERENCES}

1. Bohle A, Mackensen-Haen S, von Gise H, Grund KE, Wechrman, Bartz $C$. The consequences of tubulointerstitial changes for renal function in glomerulopathies. A morphometric cytological analysis. Pathol Res Pract 1990;186:135-44.

2. Kluth DC, Rees AJ. New approaches to modify glomerular inflammation. J Nephrol 1999;12:66-75.

3. Furie MB, Randolph GJ. Chemokines and tissue injury. Am J Pathol 1995;146:1287-301.

4. Jiang Y, Tabak LA, Valente AJ, Graves DT. Initial characterization of the carbohy-drate structure of MCP-1. Biochem Biophys Res Comm 1991;178:1400-4.

5. Grandaliano G, Valente AJ, Rozek MM, Abboud HE. Gamma interferon stimulates monocyte chemoatacticprotein (MCP-1) in human mesangial cells. J Lab Clin Med 1994;123:282-9.

6. Rollins BJ, Yoshimura T, Leonard EJ, Pobe JS. Cytokineactivated human endothelial cell synthesize and secrete a monocyte chemoattractant, MCP-1/JE. Am J Pathol 1990;136:1229-33.

7. Brady HR. Leukocyte adhesion molecules: potential targets for therapeutic intervention in kidney diseases. Curr Opin Nephrol Hypert 1993;2:171-82.

8. Rovin BH, Rumanick M, Tan L, Dickerson J. Glomerular expression of monocyte Chemoattractant protein-1 in experimental and human glomerulonephritis. Lab Invest 1994;71:536-42.

9. Prodjosudjadi W, Gerritsma JSJ, van Es LA, Daha MR, Bruijn JA. Monocyte chemoattractant protein-1 in normal and diseased kidneys: An immunohistochemical analysis. Clin Nephrol 1995;44:148-55.

10. Prodjosudjadi W, van Det NF, Verhagen NAM, Gerritsma JSJ, Bruijn JA, Daha MR, et al. Interleukin-l $\alpha$ and tumor necrosis factor- $\alpha$ modulate the production of monocyte chemoattractant protein-1 by cultured human glomerular visceral epithelial cells. Nephrology 1995;1:555-62. 
11. Kriz W, Elger $\mathbf{M}$, Nagata $\mathbf{M}$, Kretzler $\mathbf{M}$, Uiker $\mathbf{S}$, Koeppen-Hagemann I, et al. The role of podocytes in the development of sclerosis. Kidney Int 1994;45:S64-72.

12. Magil AB, Cohen AH. Monocytes and focal glomerulosclerosis. Lab Invest 1989;61:404-9.

13. Sekiguchi M, Nakao N, Takeya M, Natori Y. Glomerular expression of monocyte Chemoattractant protein-1 (MCP1) in experimental crescentic glomerulonephriti (CGN). J Am Soc Nephrol 1994;5:768 (abstract).

14. Alexopoulos E, Seron D, Hartley RB, Cameron JS.Lupus nephritis: Correlation of interstitial cells with glomerular function. Kidney Int 1990;37:100-9

15. Prodjosudjadi W, Gerritsma JSJ, Klạr-Mohamad N, Gerritsen AF, Bruijn JA, Daha MR, et al. Production and cytokine-mediated regulation of monocyte chemoattractant protein-1 by human tubular epithelial cells. Kidney Int 1995;48:1477-86.

16. Lan HY, Nikolic-Paterson DJ,Mu W, Atkins RC. Local macrophage proliferation in The progression of glomerular and tubulointerstitial injury in rat anti-GBM glomerulonephritis. Kidney Int 1995;48:753-60.

17. Kerr PG, Nikolic-Paterson DJ, Lan HY, Rainone S, Tesch G, Atkins RC. Deoxysprgualin supresses local macrophage proliferation in rat renal allograft rejection. Transplantation 1994;58:596-601.

18. Prodjosudjadi W, Daha MR, Gerritsma JSJ, Florijn KW, Barendregt JNM, Bruijn JA, Et al. Increased urinary excretion of monocyte chemoattractant protein-1 during acute renal allograft rejection. Nephrol Dial Transplant 1996;11:1096-103.

19. Moolenaar W, Bruijn JA, Schrama E, Ferrone S, Daha $\mathrm{MR}, \mathrm{Z}$ winderman $\mathrm{AH}$, et al. T cell receptors and ICAM-1 expression in renal allograft rejection. Transplant Int 1991; 4:140-5.

20. Alpers CE, Hudkins KL, Davis CL, Marsh CC, Riches W, McCarty JM,et al. Expression of vascular cell adhesion molecule- 1 in kidney allograft rejection. Kidney Int 1993;44:805-16.

21. Schlondorff D. Experimental model and therapeutic perspective. The role of chemokines in the initiation and progression of renal disease. Kidney Int 1995; 47: S44-7.

22. Schouder RL, Kunkel SL. The cytokine response in renal allograft rejection. Nephrol Dial Transplant 1995;10:36-43.

23. Tang WW, Qi M, Warren JS. Monocyte chemoattractant protein-1 mediates glomerular macrophage infiltration in anti-GBM Ab GN. Kidney Int 1996;50:665-71. 